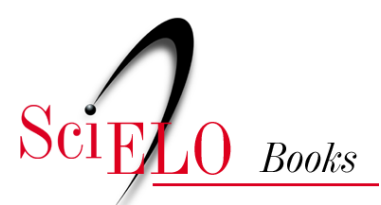

\title{
41. Arthur Neiva, Inteligência e Cultura a Serviço da Nação
}

\author{
Joffre Marcondes de Rezende
}

\section{SciELO Books / SciELO Livros / SciELO Libros}

REZENDE, J. M. Arthur Neiva, Inteligência e Cultura a Serviço da Nação. In: À sombra do plátano: crônicas de história da medicina [online]. São Paulo: Editora Unifesp, 2009, pp. 355-358. História da Medicina series, vol. 2. ISBN 978-85-61673-63-5. https://doi.org/10.7476/9788561673635.0042.

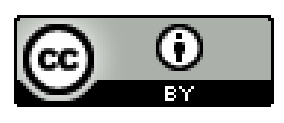

All the contents of this work, except where otherwise noted, is licensed under a Creative Commons Attribution 4.0 International license.

Todo o conteúdo deste trabalho, exceto quando houver ressalva, é publicado sob a licença Creative Commons Atribição 4.0.

Todo el contenido de esta obra, excepto donde se indique lo contrario, está bajo licencia de la licencia Creative Commons Reconocimento 4.0. 


\section{I \\ Arthur Neiva, Inteligência e Cultura a Serviço da Nação*}

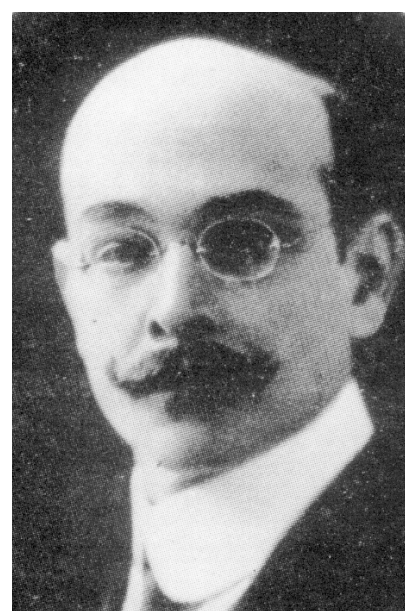

Arthur Neiva (I880-I943).

$\mathrm{D}$ entre os pesquisadores arregimentados por Oswaldo Cruz para lançar as fundações da medicina científica no Brasil sobressai a figura ímpar de Arthur Neiva. O que mais o distingue entre seus pares é a sua versatilidade, sua capacidade de desempenhar com brilhantismo as mais diversas tarefas e funções, deixando em todas elas a marca de seu talento e de sua personalidade.

Natural de Salvador, Arthur Neiva concluiu seu curso médico no Rio de Janeiro em I903. Ainda como estudante participou da campanha contra a febre amarela. Recém-formado, trabalhou como auxiliar de laboratório e preparava-se para prestar concurso para inspetor sanitário quando foi descoberto por Oswaldo Cruz.

Sua primeira missão foi a de combater a malária que se espalhava pela bacia do rio Xerém, onde se realizavam os trabalhos de captação de água para o abastecimento do Rio de Janeiro. Nessa oportunidade, Neiva aprofundou seus conhecimentos sobre os anofelinos, descreveu uma nova espécie

* Publicado em Ética Revista, 5 (5), pp. 26-27, 2007. 
de mosquito e detectou a resistência do plasmódio à quinina, o que tornava insuficientes as doses até então empregadas.

Em I9 Io foi a Washington completar seus estudos de entomologia e, de regresso ao Brasil, motivado pela descoberta da tripanossomíase por Carlos Chagas, seu interesse se voltou para os triatomídeos. Fez uma revisão do gênero Triatoma, com ênfase nas espécies transmissoras do Trypanosoma cruzi. Este trabalho foi apresentado como tese à Faculdade de Medicina do Rio de Janeiro em I9 I4, o que lhe valeu o título de livre-docente, conferido pelo voto unânime da congregação (Bacellar, I963, pp. I89-198).

Em r9 12, em companhia de Belisário Penna, realizou uma difícil viagem científica pelo interior do país, percorrendo durante sete meses o norte da Bahia, sudoeste de Pernambuco, sul do Piauí e de norte a sul de Goiás, a maior parte do trajeto em lombo de burro, dormindo ao relento ou em barracas improvisadas. O relatório desta viagem foi publicado nas Memórias do Instituto Oswaldo Cruz, em r9i6, e constitui um marco na história da ciência brasileira pela riqueza de informações sobre os aspectos geográficos, clima, flora, fauna, condições sanitárias e doenças do homem e dos animais. Retrata a realidade do interior do país, na época inteiramente desconhecida dos habitantes das cidades litorâneas, e causou um grande impacto às autoridades governamentais e à sociedade em geral, ao relatar as condições de atraso, pobreza, miséria, analfabetismo, doenças endêmicas e isolamento em que vivia a população na região por eles percorrida.

Prevendo as críticas ao retrato desolador da realidade do sertão por eles descrita, assim se pronunciaram antecipadamente: "Não agradará certamente a franqueza com que expomos nossa impressão, mas julgamos ser isso um dever de consciência e de patriotismo. É indispensável dizer a verdade embora dolorosa e cruciante e não iludir de forma alguma a Nação" (Neiva e Penna, I916, pp. 74-224).

Em I9I 3 esteve na Argentina, onde descreveu uma nova espécie de Triatoma e, em I9I 5, voltou a Buenos Aires, convidado a instalar e dirigir a Seção de Zoologia Animal e Parasitologia do Instituto Bacteriológico daquele país, onde permaneceu por dois anos, regressando ao Brasil a convite do governo do estado de São Paulo para assumir o Serviço Sanitário estadual.

Em sua nova função elaborou o código sanitário do estado de São Paulo contemplando não só as cidades como a zona rural, o qual serviu de mo- 
delo para outros estados. Em I9I 8 a epidemia de gripe espanhola atingiu São Paulo e coube a Arthur Neiva coordenar os trabalhos de atendimento à população, tendo improvisado 43 hospitais na capital e II9 no interior. Ele próprio foi vítima da epidemia.

Em I920 foi convidado pelo Instituto Kitasato a visitar o Japão, onde proferiu conferências e recebeu a mais alta condecoração daquele país - a Ordem do Sol Nascente. No mesmo ano, em missão oficial, foi encarregado de estudar a profilaxia da lepra na Noruega, Filipinas e Havaí.

Em 1923 foi nomeado diretor do Museu Nacional, onde tomou iniciativas relevantes como a criação do Boletim, a publicação dos Arquivos do Museu e de material didático escolar, a criação de um jardim de plantas medicinais e a retomada das pesquisas arqueológicas de Lund em Lagoa Santa, em Minas Gerais.

No ano seguinte, o governo do estado de São Paulo o convocou novamente para integrar a comissão incumbida de debelar a "broca" do café, praga que estava devastando a cafeicultura no estado com graves prejuízos para o país. O trabalho da comissão foi coroado de êxito e alertou o governo para a necessidade de criar-se uma instituição de bases científicas para proteção da agricultura. E assim foi fundado, em I927, o Instituto Biológico de Defesa Agrícola e Animal que, em 1937, passou a denominar-se Instituto Biológico (Lent, I940, pp. I36-I40).

Arthur Neiva foi o primeiro diretor do instituto, durante quatro anos, e teve como colaborador outro cientista de renome, que foi Henrique da Rocha Lima. Ambos elevaram bem alto o conceito e o prestígio do Instituto. Em I928 Neiva criou a revista Arquivos do Instituto Biológico para divulgação dos trabalhos desenvolvidos no instituto e, em sua gestão, foi implantado o regime de tempo integral para os jovens pesquisadores que eram admitidos. Seu lema, que gostava de repetir como um incentivo aos iniciantes era: "Trabalhe... trabalhe, nada resiste ao trabalho" (Rebouças, 2006, pp. 995-I005).

Após a Revolução de I930, Neiva se envolveu pela primeira vez com a política, ao aceitar sua nomeação para secretário do interior do estado de São Paulo. Permaneceu no cargo apenas três meses e, nesse curto prazo, tomou várias medidas que marcaram sua administração, dentre as quais a criação de um Departamento de Educação Física, o primeiro do país, e de um Serviço de Assistência aos Psicopatas. 
Em fevereiro de I93 I foi nomeado interventor na Bahia, seu estado natal, permanecendo no posto durante seis meses. Em sua administração, criou o Instituto do Cacau, em defesa do principal produto do estado.

Em maio de 1933 foi eleito deputado federal constituinte pelo estado da Bahia e reeleito no ano seguinte para um mandato na Câmara Federal. Com o golpe de estado em novembro de 1937 e a dissolução do Congresso, voltou às suas atividades no Instituto Oswaldo Cruz, onde permaneceu até I943, quando faleceu aos 63 anos de idade (Bacellar, op. cit.).

Arthur Neiva foi a um só tempo médico, pesquisador, educador, escritor, sanitarista e homem público. Sua vasta cultura, sua inteligência, seu amor ao trabalho e seu patriotismo permitiram que ele se afirmasse como líder em todos os setores onde atuou. Seu legado científico é um patrimônio no acervo da ciência e da cultura nacionais. Além da extensa bibliografia científica, escreveu vários ensaios e um livro intitulado Estudos da Lingua Nacional, que faz parte da coleção Brasiliana da Cia. Editora Nacional (Neiva, I940); como educador, formou toda uma geração de novos pesquisadores que seguiram o seu exemplo; como sanitarista, indicou os caminhos a serem trilhados para o saneamento urbano e rural; como homem público, esteve sempre pronto a servir o país, quando convocado.

O Instituto Oswaldo Cruz o homenageou, dando o seu nome a um dos pavilhões do instituto.

\section{Referências Bibliográficas}

Bacellar, R. C. Brazil's Contribution to Tropical Medicine and Malaria. Rio de Janeiro, Gráfica Olímpica Editora, I963.

Lent, H. “Arthur Neiva”. In Ribeiro, L. Medicina no Brasil. Rio de Janeiro, Imprensa Nacional, I940.

Neiva, A. Estudos da Lingua Nacional. São Paulo, Cia. Editora Nacional, I940.

Neiva, A. \& Penna, B. "Viagem Científica pelo Norte da Bahia, Sudoeste de Pemambuco, Sul do Piauhí e de Norte a Sul de Goiaz”. Memórias do Instituto Oswaldo Cruz, Rio de Janeiro, 8 (3), pp. 74-224, I9I6.

Rebouças, M. M. "Pelo Resgate da Memória Documental das Ciências e da Agricultura: o Acervo do Instituto Biológico de São Paulo". História, Ciências, Saúde Manguinhos, I3 (4), pp. 995-1005, 2006. 